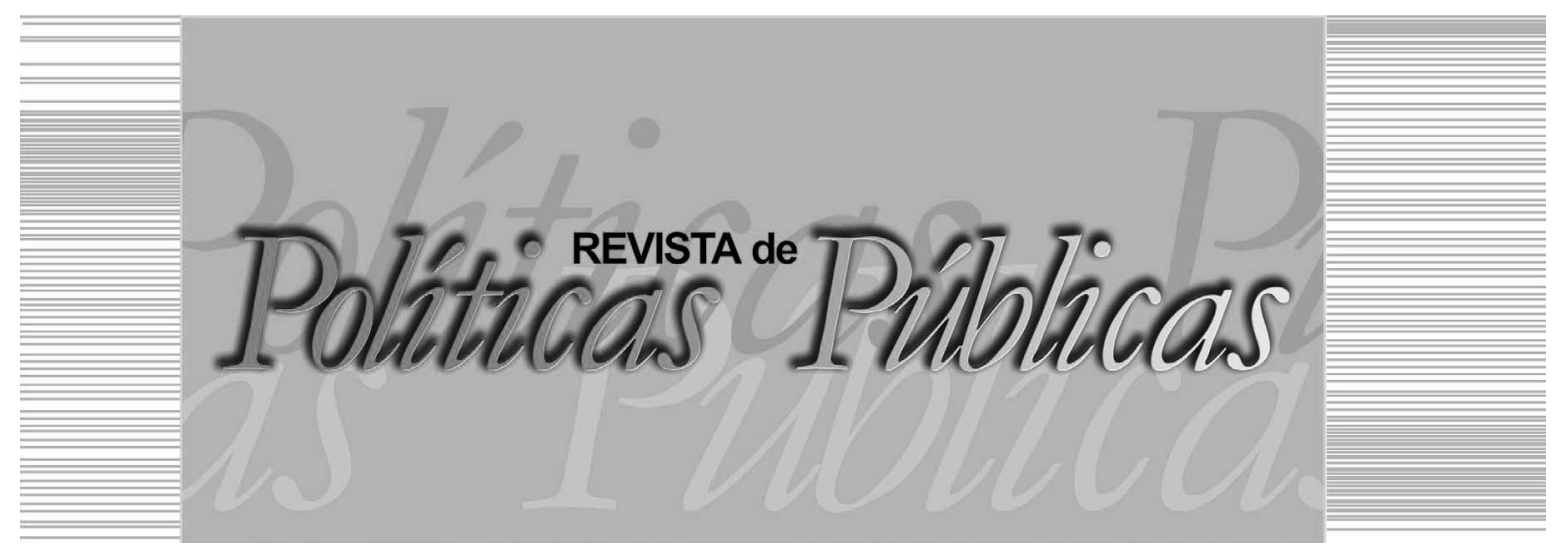

\title{
REGULARIZAÇÃO FUNDIÁRIA URBANA: uma análise comparativa legal para o nascimento da propriedade social em São Luís
}

\author{
Lourival da Silva Ramos Júnior ${ }^{l}$ \\ Priscilla Ribeiro Moraes Rêgo de Souza ${ }^{2}$
}

\section{Resumo}

O presente trabalho pretende fornecer subsídio jurídico ao problema social de posses ilegais no Município de São Luís. Faz uma análise comparativa da regularização fundiária prevista nas Leis Federais n. 11.977/09 e 13.465/17, tomando como referência o Município de São Luís. Contudo, antes de utilizá-la, é necessário conhecer os proprietários na área objeto de regularização fundiária para definição dos procedimentos da lei mais recente. Propõe duas soluções para resolver os problemas sociais de moradia: a primeira é a conversão direta de posse em propriedade, sem esperar o tempo de 05 (cinco) anos, contado do registro do título da legitimação de posse e, a segunda, a possibilidade de esse título servir como garantia de financiamento imobiliário, antes da sua conversão em propriedade.

Palavras-chave: Posse, propriedade, regularização fundiária, financiamento bancário.

\footnotetext{
Advogado, Especialista em Direito Imobiliário pela Faculdade Fortium-DF, Assessor Técnico de Correição e Inspeção da Corregedoria Geral da Justiça (CGJ/MA). E-mail: jlourival@gmail.com

2 Advogada e Contadora, Mestre em Políticas Públicas pela Universidade Federal do Maranhão (UFMA), Analista Judiciário - Direito da CGJ/MA. E-mail: priscilla.m.ribeiro@ hotmail.com / Corregedoria Geral da Justiça - CGJ/MA: Rua Engenheiro Couto Fernandes, s/nº - Centro - São Luís - Maranhão. CEP: 65.010-100
} 
URBAN FOUNDATIONAL REGULARIZATION: a comparative legal analysis for the birth of social property in São Luís

\begin{abstract}
The present work intends to provide legal support to the social problem of illegal possessions in the Municipality of São Luís. It makes a comparative analysis of land regularization foreseen in Federal Laws no. 11.977 / 09 and 13.465 / 17, taking as reference the Municipality of São Luís. However, before using it, it is necessary to know the owners in the land subject to land regularization to define the procedures of the most recent law. Two solutions were proposed to solve the social problems of housing: the first is the direct conversion of tenure into property, without waiting for the time of 05 (five) years, counting from the registration of the title of possession's legitimation, and the second, the possibility of such title serving as real estate financing guarantee, prior to its conversion into property.
\end{abstract}

Key words: Possession, property, land regularization, bank financing.

\title{
1 INTRODUÇÃO
}

Este artigo analisa um problema específico das cidades brasileiras: como resolver as ocupações urbanas ilegais sem esperar pelo longo resultado do processo judicial de usucapião? Como é possível oferecer áreas possessórias como garantia imobiliária ao financiamento bancário? Eram perguntas com respostas insolúveis até a publicação da Lei Federal n ${ }^{\circ}$ 11.977, de 9 de julho de 2009, que, posteriormente, foi substituída pela Lei $n^{\circ} 13.465$, de 11 de julho de 2017, as quais tratam sobre a regularização fundiária de assentamentos localizados em áreas urbanas.

Ademais, a nova Lei que trata sobre regularização fundiária urbana, por si só, não tem o condão de resguardar o direito à moradia. É preciso conhecer, primeiro, cada localidade, para definir o tipo de procedimento jurídico adequado. Além disso, a experiência prática, no interior do Estado, demonstrou que o prévio conhecimento dos problemas sociais implica, geralmente, soluções diversas.

Na cidade de São Luís, os problemas de moradia são observados em decorrência da urbanização desorganizada, cujas soluções jurídicas serão diferenciadas para uma mesma localidade como, por exemplo, no bairro Alemanha, onde uma parte pertence à União, por ser terreno de marinha, enquanto a outra se divide em uma área pri- 
REGULARIZAÇÃO FUNDIÁRIA URBANA DE SÃO LUÍS:

da posse legal à propriedade social

vada registrada no cartório de imóvel, onde se localiza o Conjunto Newton Bello, outra grande área ocupada ilegalmente há décadas.

De fato, no Município de São Luís, o óbice não é a informação sobre as dificuldades em cada bairro, mas sim a falta de prudência aos operadores do direito na aplicação da norma jurídica. Noutros termos, a questão não é a ciência jurídica enquanto saber, e sim a falta de adequação da Lei Federal n ${ }^{\circ} 11.977 / 2009$ e, posteriormente, da Lei n ${ }^{\mathrm{o}} 13.465 / 2017$ à realidade social.

Sendo assim, o presente trabalho busca fazer uma análise comparativa entre a Lei Federal no 11.977/2009 e a Lei ${ }^{\circ} 13.465 / 2017$, assim como a aplicação desta última para minimizar os problemas sociais do Município de São Luís, na medida em que se propõe estabelecer um procedimento básico de regularização fundiária urbana de São Luís a partir da Lei Federal mais recente, tais como a iniciativa do seu procedimento, a necessidade de abertura de matrícula imobiliária e os tipos de regularização fundiária urbana. Em seguida, far-se-á uma sugestão à Lei $n^{\circ} 11.465 / 2017$, adequada a usucapião extraordinária da Lei $\mathrm{n}^{\circ} 10.406$, de 10 de janeiro de 2002 (Código Civil - CC), com a emissão de título de legitimação de posse convertido direto em propriedade, sem necessidade de declaração judicial. Por fim, será demonstrado como a legitimação de posse pode ser utilizada como garantia de financiamento bancário.

\section{A LEI FEDERAL 11.977/2009 E AS INOVAÇÕES TRAZIDAS PELA LEI 13.465/2017}

A Lei Federal $n^{\circ}$ 11.977/2009 instituiu a chamada regularização fundiária urbana, que pretendia não apenas a transformação de posses ilegais em propriedades válidas, mas também fornecer qualidade de vida urbana e ambiental à sua população.

Em substituição à Lei supra, a Lei $n^{0} 13.465 / 2017$ criou o termo Reurb para conceituar a regularização fundiária urbana como o conjunto de "[...] medidas jurídicas, urbanísticas, ambientais e sociais destinadas à incorporação dos núcleos urbanos informais ao ordenamento territorial urbano e à titulação de seus ocupantes.", conforme art. $9^{\circ}$ da referida Lei. (BRASIL, 2017).

Essa Lei estabeleceu novos objetivos para regularização fundiária urbana; destacam-se, entre eles, conforme descrito no art. $10^{\circ}$ : criar unidades imobiliárias compatíveis com o ordenamento territo- 
rial urbano e constituir sobre elas direitos reais em favor dos seus ocupantes (inciso II); concretizar o princípio constitucional da eficiência na ocupação e no uso do solo (inciso IX); prevenir e desestimular a formação de novos núcleos urbanos informais (inciso X); e franquear participação dos interessados nas etapas do processo de regularização fundiária (inciso XII).

A Reurb compreende duas modalidades: a Reurb de Interesse Social (Reurb-S), que corresponde à regularização fundiária aplicável aos núcleos urbanos informais ocupados predominantemente por população de baixa renda, assim declarados em ato do Poder Executivo Municipal; e a Reurb de Interesse Específico (Reurb-E), aplicável aos núcleos urbanos informais ocupados por população não qualificada na primeira modalidade. (BRASIL, 2017, art. 13, incisos I e II).

Segundo a Lei $n^{0} 13.465 / 2017$, a classificação do interesse visa exclusivamente identificar responsáveis pela implantação ou adequação das obras de infraestrutura essencial e reconhecer o direito à gratuidade das custas e emolumentos notariais e registrais em favor daqueles a quem for atribuído o domínio das unidades imobiliárias regularizadas.

Ademais, a regularização fundiária é de responsabilidade de todos os entes políticos da Federação (direta e indireta), e estes formularão e desenvolverão no espaço urbano as políticas de suas competências de acordo com os princípios de sustentabilidade econômica, social e ambiental e ordenação territorial, buscando a ocupação do solo de forma eficiente, combinando seu uso de forma funcional.

Nesse contexto, convém salientar que, tanto a Lei $\mathrm{n}^{\circ}$ 11.977/2009 (revogada parcialmente) como a Lei $\mathrm{n}^{\mathrm{o}} 13.465 / 2017$ estabeleceram que qualquer pessoa física ou jurídica, pública ou privada, pode ser uma empreendedora desse projeto de regularização fundiária urbana, inclusive as serventias extrajudiciais do Maranhão. Com efeito, as pessoas físicas ou jurídicas, públicas ou privadas, serão agentes multiplicadores da regularização fundiária urbana, trabalhando em parceria com os órgãos públicos (Município de São Luís, o Ministério Público e o Poder Judiciário do Maranhão).

No caso em apreço, o Município de São Luís tem a maior concentração de núcleos habitacionais de posseiros, cujas áreas estão desvalorizadas, entre outros fatores, por falta de políticas pú- 
REGULARIZAÇÃO FUNDIÁRIA URBANA DE SÃO LUÍS:

da posse legal à propriedade social

blicas, aumento da violência social e ausência de inscrição no fólio real.

O benefício trazido pela Lei $\mathrm{n}^{\circ} 11.977 / 2009$ (art. $58^{\circ}$ ) e mantido pela Lei ${ }^{\circ} 13.465 / 2017$ (art. $25^{\circ}$ ) foi a conversão da posse em propriedade, com a emissão de documento emitido pelo Município, chamado de título de legitimação de posse, registrável no fólio real. (BRASIL, 1973b, art. 167 , I-41).

Pela Lei $n^{\circ} 11.977 / 2009$, a legitimação de posse devidamente registrada constitui direito em favor do detentor da posse direta para fins de moradia (BRASIL, 2009, caput do art. $59^{\circ}$ ), cuja conversão em propriedade dar-se-á após cinco anos do seu registro na serventia imobiliária (BRASIL, 2009, caput do art. $60^{\circ}$ ), para áreas até $250 \mathrm{~m}^{2}$ (duzentos e cinquenta metros quadrados).

Do contrário, diz o seu $\S 3^{\circ}$ do art. $60^{\circ}$ dessa Lei Federal: "No caso de área urbana de mais de $250 \mathrm{~m}^{2}$ (duzentos e cinquenta metros quadrados), o prazo para requerimento da conversão do título de legitimação de posse em propriedade será o estabelecido na legislação pertinente sobre usucapião." (BRASIL, 2009).

Contudo, a Lei n ${ }^{\circ}$ 13.465/2017 dispôs que a expedição do título de legitimação de posse constitui direito em favor do detentor da posse direta para fins de moradia, após cinco anos do seu registro, cuja conversão em propriedade dar-se-á de forma automática, desde que atendidos os termos e as condições do art. $183^{\circ}$, da Constituição Federal de 1988, independentemente de prévia provocação ou prática de ato registral (BRASIL, 2017, caput do art. $26^{\circ}$ ).

Além disso, a referida Lei, em seu $\S 1^{\circ}$ do art. $26^{\circ}$, dispõe que:

Nos casos não contemplados pelo art. 183, da Constituição Federal, o título de legitimação de posse poderá ser convertido em título de propriedade, desde que satisfeitos os requisitos de usucapião estabelecidos na legislação em vigor, a requerimento do interessado, perante o registro de imóveis competente. (BRASIL, 2017).

Assim, observa-se que a Lei ${ }^{\circ} 13.465 / 2017$ buscou facilitar a conversão posse, para fins de moradia, em propriedade, determinando que ela se dará de forma automática, desde que obedecidos os requisitos do art. $183^{\circ}$, da Constituição Federal (CF).

Ressalta-se que a Lei $\mathrm{n}^{\circ} 11.977 / 2009$, ao conceituar legitimação de posse (art. 47, inciso IV), dispôs que é "[...] ato do poder 
público destinado a conferir título de reconhecimento de posse de imóvel objeto de demarcação urbanística, com a identificação do ocupante e do tempo e natureza da posse." (BRASIL, 2009).

Nesse caso, nos termos da referida Lei, o título de legitimação de posse não decorria somente do auto de demarcação urbanística ${ }^{1}$, mas também de outros procedimentos não previstos legalmente, tais como na legitimação fundiária ${ }^{2}$ (prevista na Lei $n^{\circ} 13.465 / 2017$ ). Ressalta-se que, quando o beneficiário individual inicia o procedimento de regularização de sua posse (BRASIL, 2009, art. 50 $0^{\circ}$ ), não há exigência legal de auto de demarcação para emissão de título de legitimação de posse, bem como esse procedimento administrativo tornar-se-á burocrático e financeiramente inacessível à população de baixa renda.

Aliás, o art. $288^{\circ}$-D da Lei $n^{\circ} 6.015$, de 31 de dezembro de 1973 (Lei de Registros Públicos), que atualmente se encontra revogada pela Lei $\mathrm{n}^{\circ} 13.465 / 2017$, somente obrigava ao Município que fizesse o requerimento ao registro de imóveis para averbar a demarcação urbanística, sem qualquer obrigação símil ao beneficiário individual.

Já a Lei n ${ }^{\circ} 13.465 / 2017$, em seu art. $11^{\circ}$, inciso VI, conceituou a legitimação de posse como um "[...] ato do poder público destinado a conferir título, por meio do qual fica reconhecida a posse de imóvel objeto da Reurb, conversível em aquisição de direito real de propriedade na forma desta Lei, com a identificação de seus ocupantes, do tempo da ocupação e da natureza da posse." (BRASIL, 2017).

Ademais, a nova Lei de regularização fundiária não manteve o dispositivo legal que exigia o auto de demarcação urbanística para concessão do título de legitimação de posse do detentor.

Sendo assim, basta que o beneficiário (ocupante) prepare a documentação de regularização fundiária urbana de sua área, passe pelo crivo do Município e, ato contínuo, receba deste órgão o título de legitimação de posse, a fim de o beneficiário levá-lo ao registro de imóvel competente.

Desse modo, o que se propõe é a divulgação de um procedimento básico de regularização fundiária urbana para o Município de São Luís, que poderá ser elaborado em parceria com órgãos públicos (União, Estado, Ministério Público e Poder Judiciário), conforme a área objeto de regularização fundiária seja pública ou privada, tais 
REGULARIZAÇÃO FUNDIÁRIA URBANA DE SÃO LUÍS:

da posse legal à propriedade social

como no bairro do João Paulo e Alemanha, onde também coexistem propriedades pública e privada.

É conveniente, portanto, seguir as seguintes etapas propostas ao procedimento de regularização fundiária urbana, tais como: (i) conhecer e delimitar as áreas públicas, separando-as das privadas por exclusão; (ii) delimitar, por estimativa, dentro das áreas privadas, as que são iguais ou superiores a $250 \mathrm{~m}^{2}$, bem como as áreas iguais ou inferiores a $250 \mathrm{~m}^{2}$; (iii) em seguida, estabelecer procedimento de regularização fundiária urbana de interesse social ou de interesse específico e, por fim, (iv) fixar os critérios de análise do projeto de regularização fundiária pela Município de São Luís/MA.

\section{PROPOSTA DE REGULARIZAÇÃO FUNDIÁRIA URBANA DE SÃO LUÍS}

Por ser uma Ilha costeira marítima, a maior parte das áreas do Município de São Luís pertence à União, especificamente nos chamados terrenos de marinha, os quais não foram alcançados pelo inciso IV do art. 20 da Constituição Federal, alterada pela Emenda Constitucional $\mathrm{n}^{\circ} 46$, de 5 de maio de 2005 , a saber: IV - as ilhas fluviais e lacustres nas zonas limítrofes com outros países; as praias marítimas; as ilhas oceânicas e as costeiras, excluídas, destas, as que contenham a sede de Municípios, exceto aquelas áreas afetadas ao serviço público e a unidade ambiental federal, e as referidas no art. 26, II; (BRASIL, 2005).

Sendo assim, é necessário recorrer à Secretária de Patrimônio da União (SPU) e, eventualmente, às $1^{\mathrm{a}}$ e $2^{\mathrm{a}}$ Zonas de Registro de Imóveis de São Luís para obter informações precisas da localização de propriedades da União, notadamente dos terrenos de marinha. Ademais, as áreas ambientais de mangues e de praias também deverão ser separadas das áreas privadas.

Quanto aos bens ambientais, são públicos de uso comum do povo, e não de uso especial ou dominicais, isto é, os bens ambientais são patrimônio nacional, ainda que não estejam dentro das áreas delimitadas pelo $\S 4^{\circ}$ do art. $225^{\circ}$ da CF de 1988 , in verbis:

\footnotetext{
A Floresta Amazônica brasileira, a Mata Atlântica, a Serra do Mar, o Pantanal Mato-Grossense e a Zona Costeira são patrimônio nacional, e sua utilização far-se-á, na forma da lei, dentro de condições que assegurem a preservação do meio ambiente, inclusive quanto ao uso dos recursos naturais. (BRASIL, 1988, grifo nosso).
} 
Noutros termos, são bens administrativos que contêm limitação administrativa oriunda da própria Constituição Federal, prescindível de inscrição no acervo de registro de imóvel (fólio real).

Quanto aos demais entes estatais (Estado e Município), as informações serão obtidas respectivamente no Instituto de Terras do Estado do Maranhão (ITERMA) e no órgão municipal específico sobre urbanização de São Luís, sem prejuízo de outros dados constantes nos órgãos da administração pública ou em instituições privadas.

No que se refere às áreas devolutas, não se considera que a ausência de registro de imóveis resulte automaticamente em um bem público, consoante entendimento pacificado no Supremo Tribunal Federal, in verbis:

Com efeito, não se pode desconhecer que a mera ausência de regis-
tro imobiliário não é suficiente, só por si, para configurar a existên-
cia de domínio público, mesmo porque tal circunstância não induz
à presunção, ainda que "juris tantum", de que as terras destituídas
de inscrição no Registro de Imóveis sejam necessariamente devo-
lutas, consoante tem proclamado a jurisprudência do Supremo Tri-
bunal Federal, que exige, do Estado, a prova inequívoca de que lhe
pertence à titularidade dominial do bem imóvel. (BRASIL, 2012,
grifos nossos).

Por outro lado, também é necessário conhecer quais são as áreas em conflitos judiciais dentro do Município de São Luís, a fim de excluí-las do procedimento de regularização fundiária urbana, exceto se houver previamente extinção do feito judicial.

Eis aí, portanto, um procedimento básico para que qualquer pessoa (pública ou privada) possa desenvolver ou adequá-lo à sua necessidade específica de regularização fundiária urbana no Município de São Luís/MA.

\subsection{Da Regularização Fundiária pela Lei no ${ }^{0}$ 13.465/2017}

$\mathrm{O}$ art. $14^{\circ}$ da Lei $\mathrm{n}^{\circ} 13.465 / 2017$ conferiu legitimidade aos proprietários de imóveis ou de terrenos, loteadores ou incorporadores, assim como a Defensoria Pública, em nome dos beneficiários hipossuficientes e o Ministério Público, para requerer a regularização fundiária urbana.

Contudo, o requerimento de instauração da Reurb por proprietários de terreno, loteadores e incorporadores que tenham dado 
REGULARIZAÇÃO FUNDIÁRIA URBANA DE SÃO LUÍS:

da posse legal à propriedade social

causa à formação de núcleos urbanos informais, ou os seus sucessores, não os eximirá de responsabilidades administrativa, civil ou criminal, nos termos do art. $14^{\circ}, \S 10$, da Lei ${ }^{\circ} 13.465 / 2017$. (BRASIL, 2017).

No caso, estima-se que há muitas áreas devolutas no Município de São Luís, seja porque não têm registro imobiliário, seja porque não se encontram em terrenos de marinhas e/ou áreas ambientais (federais ou estaduais), nas quais podem os seus ocupantes requerer diretamente à serventia o registro da regularização fundiária. (BRASIL, 2017, art. $42^{\circ}$ ).

Nesse sentido, após a aprovação dos projetos de regularização fundiária (de interesse específico e de interesse social) e da emissão do certificado de regularização fundiária (CRF), emitido pelo Município, os legitimados devem procurar diretamente a serventia extrajudicial para abertura de matrículas das áreas objeto de titulação, se não houver registro ou matrícula anterior.

Identicamente à Lei ${ }^{\circ} 11.977 / 2009$, a Lei no $13.465 / 09$ estabeleceu dois tipos de regularização fundiária urbana: interesse social e interesse específico, as quais foram conceituadas pelos incisos I e II do art. $13^{\circ}$ da Lei $\mathrm{n}^{\circ} 13.465 / 2017$, a saber:

Art. 13. A Reurb compreende duas modalidades:

I - Reurb de Interesse Social (Reurb-S) - regularização fundiária aplicável aos núcleos urbanos informais ocupados predominantemente por população de baixa renda, assim declarados em ato do Poder Executivo municipal; e

II - Reurb de Interesse Específico (Reurb-E) - regularização fundiária aplicável aos núcleos urbanos informais ocupados por população não qualificada na hipótese de que trata o inciso I deste artigo. (BRASIL, 2017).

Nessa situação, a legislação utilizou o critério econômico que será fixado por cada Município, conforme suas realidades factuais -, para definição de regularização fundiária de interesse social, enquanto que a de interesse específico definiu-se por exclusão da primeira.

A Lei ${ }^{\circ} 13.465 / 2017$ determinou que o tamanho da área de até $250 \mathrm{~m}^{2}$ (duzentos e cinquenta metros quadrados) não caracteriza a regularização fundiária de interesse social (Reurb-S), mas serve como critério temporal de conversão em propriedade, a partir da le- 
gislação específica sobre usucapião (constitucional ou CC), conforme $\mathrm{o}$ art. $26^{\circ}, \S 1^{\circ}$, descrito a seguir:

Art. 26. Sem prejuízo dos direitos decorrentes do exercício da posse mansa e pacífica no tempo, aquele em cujo favor for expedido título de legitimação de posse, decorrido o prazo de cinco anos de seu registro, terá a conversão automática dele em título de propriedade, desde que atendidos os termos e as condições do art. 183 da Constituição Federal, independentemente de prévia provocação ou prática de ato registral.

$\S 1^{\circ}$ Nos casos não contemplados pelo art. 183 da Constituição Federal, o título de legitimação de posse poderá ser convertido em título de propriedade, desde que satisfeitos os requisitos de usucapião estabelecidos na legislação em vigor, a requerimento do interessado, perante o registro de imóveis competente. (BRASIL, 2017, grifo nosso)

Noutros termos, se o legitimado ocupar ininterruptamente uma área de até $250 \mathrm{~m}^{2}$ (duzentos e cinquenta metros quadrados) sem oposição, utilizando-a para sua moradia ou de sua família, adquirir-lhe-á o domínio, após cinco anos do registro da Reurb-S (BRASIL, 1988, art. $183^{\circ}, 2017$, art. $26^{\circ}$ ).

Do contrário, não preenchendo os requisitos acima, tais como, não ocupar ininterruptamente uma área de até $250 \mathrm{~m}^{2}$, o legitimado poderá solicitar a conversão da sua posse em propriedade, a partir do registro desse título no fólio real, em 15 (quinze) ou 10 (dez) anos, nos termos previstos para usucapião extraordinária, nos termos do art. $1.238^{\circ} 3$ do CC combinado com o $§ 1^{\circ}$ do art. 26 da Lei $\mathrm{n}^{\mathrm{o}} 13.465 / 2017$. (Figura 1).

Figura 1 - Tipos de regularização fundiária

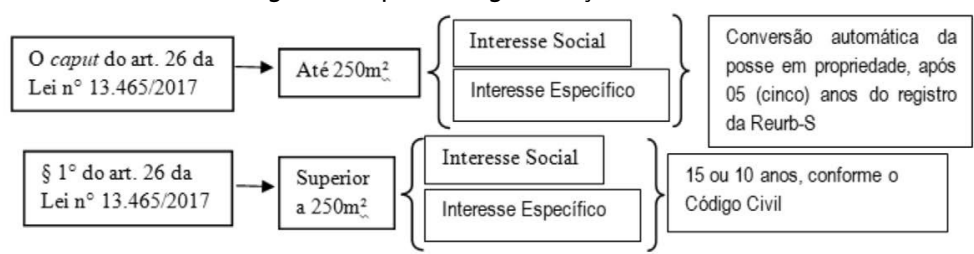

Fonte: Elaborado pelos autores, a partir de: BRASIL. Presidência da República. Lei n 11.977, de 7 de julho de 2009. Dispõe sobre o Programa Minha Casa, Minha Vida - PMCMV e a regularizacão fundiária de assentamentos localizados em áreas urbanas ... Diário Oficial da União, Brasília DF, 8 jul. 2009. Disponível em: <http://www.planalto.gov.br/ccivil_03/_ato2007-2010/2009/lei/ L11977compilado.htm>. Acesso em: 13 mai. 2016. 
REGULARIZAÇÃO FUNDIÁRIA URBANA DE SÃO LUÍS:

da posse legal à propriedade social

Desse modo, o que diferencia os tipos de regularização fundiária urbana de interesse social, do interesse específico, são as hipóteses normativas da Lei $\mathrm{n}^{\circ} 13.465 / 2017$, e não o tamanho de área de até $250 \mathrm{~m}^{2}$ (duzentos e cinquenta metros quadrados) que serve para os tipos de usucapião constitucional e do CC.

\section{TÍTULO DE LEGITIMAÇÃO DE POSSE}

A regularização fundiária urbana é mais adequada para resolver problemas de ocupações ilegais sem recorrer ao Poder Judiciário, por meio da chamada legitimação de posse, que foi conceituada, conforme inciso IV do art. $47^{\circ}$ da Lei n' $11.977 / 2009$, como um " “.... ato do poder público destinado a conferir título de reconhecimento de posse de imóvel objeto de demarcação urbanística, com a identificação do ocupante e do tempo e natureza da posse." (BRASIL, 2009).

Registre-se que o caput do art. $25^{\circ}$ da Lei ${ }^{\circ} 13.465 / 2017$ conceituou a legitimação de posse, como um "[...] instrumento de uso exclusivo para fins de regularização fundiária, constitui ato do poder público destinado a conferir título, [...], com a identificação de seus ocupantes, do tempo da ocupação e da natureza da posse." (BRASIL, 2017).

A legitimação de posse não ocorre somente em áreas privadas ou devolutas, mas também em área pública, destinadas exclusivamente à regularização fundiária de interesse social, em razão do benefício da dispensa de licitação, nos termos do art. $17^{\circ}$, inciso I-f, da Lei $\mathrm{n}^{\circ} 8.666$, de 21 de junho de 1993, bem como a averbação da construção independe de prova de inexistência de débito previdenciário, nos termos da letra e do $\S 6^{\circ}$ do inciso II do art. $47^{\circ}$ da Lei n ${ }^{\circ}$ 8.212, de 24 de julho de 1991.

Aliás, a legitimação de posse em terras públicas não é novidade da Lei ${ }^{\circ} 13.465 / 2017$, pois já existia no art. $5^{\circ}$ da Lei $n^{\circ} 601$, de 18 de dezembro de 1850 (Lei de Terras); sendo prevista, depois, no art. $57^{\circ}$ combinado com o art. $164^{\circ}$, ambos do Decreto-Lei $n^{\circ} 9.760$, de 5 de setembro de 1946 (dispõe sobre bens imóveis da União) e, por fim, no art. $29^{\circ}$ da Lei n ${ }^{\circ} 6.383$, de 7 de dezembro de 1976 (dispõe sobre processo discriminatório de terras devolutas da União). 
Contudo, a diferença da legitimação de posse das citadas Leis Federais da legitimação de posse da Lei $n^{\circ}$ 13.465/2017 é a gratuidade na sua concessão e no seu registro imobiliário.

No processo discriminatório de terras devolutas da União, o $\S 1^{\circ}$ do art. $29^{\circ}$ da Lei $n^{\circ} 6.383 / 1976$ diz que a legitimação de posse consiste no fornecimento de uma licença de ocupação para o uso, de no mínimo, de quatro anos, findo o qual o ocupante terá preferência para aquisição do lote ocupado. No mesmo sentido dispõe o Decreto-Lei sobre bens da União, ao dizer que a legitimação de posse decorrerá do pagamento da taxa de legitimação (Decreto-Lei $\mathrm{n}^{\circ} 9.760$, de 5 de setembro de 1946, caput do art. 164).

Quanto à natureza jurídica da legitimação de posse da Lei $n^{0}$ 13.465/2017, tem configuração de posse, embora registrável no livro de registro de imóvel (fólio real), consoante o art. $167^{\circ}$, inciso I-41, da Lei $n^{\circ} 6.015 / 1973$, visto que as referidas Leis usam o termo conversão da legitimação de posse em propriedade, em vez de consolidação da legitimação de posse em domínio, reforçando a ideia possessória daquela legitimação.

Contudo, a legitimação de posse tem uma noção jurídica diversa em relação à posse do art. $1.196^{\circ}$ do $\mathrm{CC}^{4}$, que manteve o texto similar ao art. $485^{\circ}$ do $\mathrm{CC}$ de $1916^{5}$.

Desde o CC de 1916, o direito civil brasileiro reconhece a posse como um mero estado de fato que tutela os seus efeitos possessórios. Nos comentários daquele Código, Clóvis Beviláqua (1956, p. 39) afirmava o seguinte:

\begin{abstract}
A posse, considerada em si mesma, funda-se em um mero fato e se apresenta como estado de fato; mas uma vez firmada, nela a ordem jurídica, em atenção à paz social e à personalidade humana, respeita o que ela apresenta ser, reconhece o jus possessionis, o direito de posse, que os interditos defendem. Eis a explicação desta forma especial do direito. É um interesse que a lei protege; portanto, é um direito.
\end{abstract}

Ademais, para além dos efeitos possessórios, Beviláqua (1956, p. 29) também dizia que o CC de 1916 adotou a teoria objetiva de Jhering "[...]quanto ao conceito de posse como uma visibilidade da propriedade.", reconhecendo-a como um direito real, e não pessoal. 
REGULARIZAÇÃO FUNDIÁRIA URBANA DE SÃO LUÍS:

da posse legal à propriedade social

Entretanto, ainda que tenha visibilidade da propriedade com natureza de direito real, isso não tem o condão de atribuir à posse a natureza de direito de propriedade (BRASIL, 1916, art. 674 ${ }^{\circ 6}$, BRASIL, 2002, art. $1.225^{\circ 7}$ ), razão pela qual o sistema de registro público brasileiro aproxima-se do sistema alemão, porque os incisos I e II do art. $167^{\circ}$ da Lei ${ }^{\circ} 6.015 / 1973$ não alcançam os atos e negócios jurídicos possessórios no fólio real.

Com efeito, a transmissão da posse não significa disposição sobre a coisa, mas apenas a transmissão temporal de ocupação da coisa para fins de usucapião e proteção possessória. Nesse aspecto, Tepedinho (2011, p. 46, grifo nosso) afirma que:

\begin{abstract}
Admitida a posse como direito subjetivo, discute-se a natureza real ou pessoal do direito possessório. Na construção de Jhering, a posse foi concebida como direito real, e a significar 'uma relação imediata da pessoa com a coisa'. [...] Martin Wolff, no direito alemão, afirma que, ao contrário da propriedade e de outros direitos reais definitivos, o BGB [Bürgerliches Gesetzbuch] não inclui a posse como direito real. Argumenta, ainda, que o sistema registrário não abrange a posse.
\end{abstract}

Assim, o conceito de disposição abrange não somente a transmissão da coisa em si mesma, mas também a transmissão dos direitos inerentes a ela, tais como o direito usar, gozar e dispor. (SCHAPP, 2010).

Por outro lado, a legitimação de posse da Lei $n^{0}$ 13.465/2017 - antes de sua conversão em propriedade - é transferível por causa mortis ou por ato inter vivos (BRASIL, 2017, art. $25^{\circ}, \S 1^{\circ}$ ), configurando-se um direito disponível e, por conseguinte, passível de inscrição no fólio real, nos termos do art. $167^{\circ}$, inciso I-41, da Lei $\mathrm{n}^{\circ} 6.015 / 1973$.

Nessa esteira, como a legitimação da posse é um direito disponível, é possível a constituição do direito real de garantia sem o desapossamento do bem (penhor, hipoteca e anticrese - arts; $1.419^{\circ}$ a $1.430^{\circ}$ do CC) ou, ainda, do direito real em garantia com transferência do bem sem o desapossamento da coisa (alienação fiduciária da propriedade imóvel - caput do art. $22^{8}$ da Lei no 9.514 , de 20 de novembro de 1997), conforme dispõe Penteado (2008).

Nesse contexto, é possível afirmar que o ocupante de área objeto de regularização fundiária pode obter financiamento imobiliário 
junto ao Sistema Financeiro de Habitação, dando como garantia o seu direito sobre a legitimação de posse.

Estima-se que grande parte das áreas privadas e sem conflito judicial no Município de São Luís estão acima de $250 \mathrm{~m}^{2}$ (duzentos e cinquenta metros quadrados) sem preencher o requisito constitucional do art. $183^{\circ} \mathrm{da} \mathrm{CF} / 1988$, invocando, assim, a norma do $\S 1^{\circ}$ do art. $26^{\circ}$ da Lei ${ }^{\circ} 13.465 / 2017$.

Nesse ponto, cabe analisar a finalidade dessa disposição normativa que remete à legislação especial de usucapião, no caso, o caput do art. $1.238^{9}$ do CC, que deixa evidente os seus pressupostos: (i) a posse; (ii) uso manso e pacífico; (iii) tempo e (iv) animus domini (a intenção de ter a coisa como dono).

Não se olvide que, na usucapião extraordinária, não importa se o tamanho da área é superior ou inferior a $250 \mathrm{~m}^{2}$ (duzentos e cinquenta metros quadrados), nem se o ocupante está de boa ou má-fé, tampouco se há título justo, mas, ao revés, se o ocupante observou aqueles pressupostos legais mencionados.

Ora, uma vez preenchido tais requisitos do art. $1.238^{\circ}$ do CC, adquire-se o direito à propriedade, possível de declaração judicial de usucapião, resultando numa sentença de natureza declaratória, cujo efeito no registro imobiliário, nos termos do art. $167^{\circ}$, I-28, da Lei n 6.015/1973, é apenas para fins de publicidade e transmissão a terceiros, em observância ao princípio da continuidade registral. (BRASIL, 1973b, art. $195^{\circ}$ ).

$\mathrm{Na}$ espécie, quando o Município (ou a autoridade licenciadora) aprova o projeto de regularização fundiária urbana de interesse social ou de interesse específico, implica um reconhecimento administrativo sobre o direito à propriedade plena que se encontra no patrimônio jurídico do ocupante da área objeto de regularização fundiária, sem prejuízo de decisão judicial em contrário.

Segundo Tepedinho (2011, p. 276), considera-se plena a propriedade que "[...] reúne em torno do seu titular todas as faculdades que compõem a senhoria, assim considerada o núcleo de aproveitamento econômico do domínio faculdades de usar, fruir e dispor da coisa".

Uma vez preenchidos os requisitos ex lege para declaração judicial de usucapião extraordinário, com maior razão dar-se-á no âmbito administrativo da regularização fundiária de interesse social 
REGULARIZAÇÃO FUNDIÁRIA URBANA DE SÃO LUÍS:

da posse legal à propriedade social

ou de interesse específico, com área superior ou inferior a $250 \mathrm{~m}^{2}$ (duzentos e cinquenta metros quadrados), com vistas ao beneficiário do projeto da regularização fundiária urbana receber o seu título de legitimação de posse convertido em propriedade, passível de registro imobiliário, nos termos do art. $167^{\circ}$, I-42, da Lei n ${ }^{\circ} 6.015 / 1973^{10}$.

Desse modo, se juridicamente é desnecessário esperar 05 (cinco) anos, do registro do título de legitimação de posse até a sua conversão em propriedade, quando se tratar de área superior a 250 $\mathrm{m}^{2}$ (duzentos e cinquenta metros quadrados), com maior razão, é despiciendo aos ocupantes de áreas inferiores a $250 \mathrm{~m}^{2}$ (duzentos e cinquenta metros quadrados) esperar o mesmo lapso temporal, quando observarem os requisitos dessa norma de usucapião extraordinária, visto que a Lei n ${ }^{\circ} 13.465 / 2017$ não traz nenhum dispositivo restringindo proposta de emissão de título de legitimação de posse convertido direto em propriedade.

\section{CONCLUSÃO}

Como visto nas linhas anteriores, este trabalho fez uma análise comparativa da regularização fundiária prevista nas Leis Federais $\mathrm{n}^{\circ} \mathrm{s} 11.977 / 2009$ e 13.465/2017, tomando como referência o Município de São Luís, onde coexistem várias propriedades públicas e privadas, pressupondo soluções diversas para concessão de títulos dominiais aos ocupantes ilegais, com a participação de vários atores sociais.

Inicialmente, é necessário individualizar as áreas que serão regularizadas, separando as públicas das privadas, para estabelecer procedimentos complementares ao previsto na Lei ${ }^{\circ} 13.465 / 2017$, para converter posse em propriedade, que é uma forma indireta de usucapião administrativo.

Nesse ponto, a ideia de regularização fundiária tem uma finalidade social muito importante contra o déficit habitacional, ocasionada pela ausência de registro anterior nas serventias extrajudiciais, razão pela qual o art. $216^{\circ}$-A da Lei $n^{\circ} 6.015 / 1973$, alterada pelo art. $7^{\circ}$ da Lei ${ }^{\circ} 13.465 / 2017$, que trata de usucapião administrativo, permitiu a abertura de matrícula, se for o caso.

Quanto ao tempo de 05 (cinco) anos para conversão da posse em propriedade, demonstrou-se a desnecessidade de aguardar esse lapso temporal quando se preenchem os requisitos legais da usuca- 
pião extraordinária do $\mathrm{CC}$, pois, do contrário, as pessoas deveriam recorrer ao Poder Judiciário, algo que iria de encontro à própria lógica da Lei ${ }^{\circ} 13.465 / 2017$, cuja pretensão é resolver as posses ilegais pela via administrativa, de maneira menos burocratizada, sem perder a segurança jurídica do direito imobiliário.

Em relação ao problema de valorização de áreas ocupadas ilegalmente, especialmente sobre o financiamento imobiliário, a Lei $\mathrm{n}^{\circ} 13.465 / 2017$ permitiu indiretamente a possibilidade de financiamento bancário por meio da legitimação de posse, visto que a referida Lei admite expressamente a disponibilidade jurídica de bens imóveis registrados sob o título da legitimação de posse, algo que não era previsto expressamente na Lei Federal no 11.977/2009.

Pelas razões discutidas neste trabalho, fez-se uma proposta de interpretação da regularização fundiária urbana da Lei $\mathrm{n}^{\circ}$ 13.465/2017, para solver os problemas sociais do Município de São Luís, promovido por setores público e privado, auxiliado por financiamento bancário acessível à população.

\section{REFERÊNCIAS}

BEVILÁQUA, C. Direito das coisas. Atualização de José de Aguiar Dias. 4. ed. Rio de Janeiro: Editora Forense, 1956.

BRASIL. Constituição. Constituição da República Federativa do Brasil de 1988. Brasília, DF, 1998. Disponível em:<http://www. planalto.gov.br/ccivil_03/Constituicao/Constituicao.htm>. Acesso em: 4 abr. 2016.

Presidência da República. Emenda constitucional no 46 , de 5 de maio de 2005. Altera o inciso IV do art. 20 da Constituição Federal. Diário Oficial da União, Brasília, DF, 6 maio 2005. Disponível em:<http://www.planalto.gov.br/ccivil_03/Constituicao/Emendas/ Emc/emc46.htm>. Acesso em: 13 mai. 2016.

Lei $\mathrm{n}^{\circ} 10.406$, de 10 de janeiro de 2002. Institui o Código Civil. Diário Oficial da União, Brasília, DF, 11 jan. 2002. Disponível em: $<$ http://www.planalto.gov.br/ccivil_03/leis/2002/ L10406.htm>. Acesso em: 6 abr. 2016.

. Lei $\mathrm{n}^{\circ} 3.071$, de $1^{\circ}$ de janeiro de 1916. Código Civil dos Estados Unidos do Brasil. Revogada pela Lei n ${ }^{\circ} 10.406$, de 10 de janeiro de 2002. Diário Oficial da União, Brasília, DF, 5 jan. 1916. 
REGULARIZAÇÃO FUNDIÁRIA URBANA DE SÃO LUÍS:

da posse legal à propriedade social

Disponível em: $<$ http://www.planalto.gov.br/ccivil_03/leis/L3071. htm>. Acesso em: 6 abr. 2016.

. Lei $\mathrm{n}^{\circ} 6.015$, de 31 de dezembro de 1973. Dispõe sobre os registros públicos, e dá outras providências. Diário Oficial da União, Brasília, DF, 31 dez. 1973b. Disponível em: <http://www. planalto.gov.br/ccivil 03/leis/L6015original.htm>. Acesso em 4 abr. 2016.

Lei $\mathrm{n}^{\circ}$ 9.514, de 20 de novembro de 1997. Dispõe sobre o Sistema de Financiamento Imobiliário, institui a alienação fiduciária de coisa imóvel e dá outras providências. Diário Oficial da União, Brasília, DF, 21 nov. 1997. Disponível em:<http://www. planalto.gov.br/ccivil_03/leis/L9514.htm>. Acesso em: 10 abr. 2016.

. Lei n ${ }^{\circ} 11.977$, de 7 de julho de 2009. Dispõe sobre o Programa Minha Casa, Minha Vida - PMCMV e a regularização fundiária de assentamentos localizados em áreas urbanas ... Diário Oficial da União, Brasília, DF, 8 jul. 2009. Disponível em: $<$ http://www.planalto.gov.br/ccivil_03/ ato2007-2010/2009/lei/ L11977compilado.htm>. Acesso em: 13 mai. 2016.

. Lei $\mathrm{n}^{\mathrm{o}} 13.465$, de 11 de julho de 2017. Dispõe sobre a regularização fundiária rural e urbana, sobre a liquidação de créditos concedidos aos assentados da reforma agrária e sobre a regularização fundiária no âmbito da Amazônia Legal; institui mecanismos para aprimorar a eficiência dos procedimentos de alienação de imóveis da União; .... Diário Oficial da União, Brasília, DF, 12 jul. 2017. Disponível em:<http://www.planalto.gov.br/ccivil_03/_ato20152018/2017/lei/L13465.htm>. Acesso em: 23 jul. 2017.

Supremo Tribunal Federal. Agravo Regimental no Recurso Extraordinário com Agravo n. 679.350/PI, da Segunda Turma. Agravante: Estado do Piauí. Agravado: José Lustosa de Melo e outro. Relator: Ministro Celso de Mello. Brasília, DF, 12 de junho de 2012. Diário da Justiça Eletrônico, Brasília, DF, n. 150, 1 ago. 2012. Disponível em: <http://www.stf.jus.br/portal/processo/verProcesso Andamento.asp?incidente=4221802> . Acesso em: 4 abr. 2016.

PENTEADO, M. B. O penhor de ações no direito brasileiro. São Paulo: Malheiros Editora, 2008.

SCHAPP, J. Direito das coisas: Sachenrecht. 3. ed. Porto Alegre: Sergio Antonio Fabris Editor, 2010. 
TEPEDINHO, G. Comentários ao Código Civil: direito das coisas. Coordenação de Antonio Junqueira de Azevedo. São Paulo: Saraiva, 2011.

\section{Notas}

1 O auto de demarcação urbanística que é simplesmente uma delimitação territorial objeto de regularização fundiária, averbada na matrícula da serventia extrajudicial (BRASIL, 1973b, art. $167^{\circ}$, II-26), para fins de emissão de títulos de legitimação de posse em nome dos ocupantes cadastrados pelo Município.

2 A legitimação fundiária, conforme art. $23^{\circ}$, da Lei $n^{\circ} 13.465 / 2017$, “[...] constitui forma originária de aquisição do direito real de propriedade conferido por ato do poder público, exclusivamente no âmbito da Reurb, àquele que detiver em área pública ou possuir em área privada, como sua, unidade imobiliária com destinação urbana, integrante de núcleo urbano informal consolidado existente em 22 de dezembro de 2016.” (BRASIL, 2017).

3 “Art. 1.238. Aquele que, por quinze anos, sem interrupção, nem oposição, possuir como seu um imóvel, adquire-lhe a propriedade, independentemente de título e boa-fé; podendo requerer ao juiz que assim o declare por sentença, a qual servirá de título para o registro no Cartório de Registro de Imóveis. Parágrafo único. O prazo estabelecido neste artigo reduzir-se-á a dez anos se o possuidor houver estabelecido no imóvel a sua moradia habitual, ou nele realizado obras ou serviços de caráter produtivo." (BRASIL, 2002).

4 “Art. 1.196. Considera-se possuidor todo aquele que tem de fato o exercício, pleno ou não, de algum dos poderes inerentes à propriedade.” (BRASIL, 2002).

5 “Art. 485. Considera-se possuidor todo aquele, que tem de fato o exercício, pleno, ou não, de algum dos poderes inerentes ao domínio, ou propriedade." (BRASIL, 1916).

6 “Art. 674. São direitos reais, além da propriedade: I - A enfiteuse; II - As servidões; III - O usufruto; IV - O uso; V - A habitação; VI - As rendas expressamente constituídas sobre imóveis; VII - O penhor; VIII - A anticrese; IX - A hipoteca.” (BRASIL, 1916).

7 “Art. 1.225. São direitos reais: I - a propriedade; II - a superfície; III - as servidões; IV - o usufruto; V - o uso; VI - a habitação; VII - o direito do promitente comprador do imóvel; VIII - o penhor; IX - a hipoteca; X - a anticrese; XI - a concessão de uso especial para fins de moradia; XII - a concessão de direito real de uso." (BRASIL, 2002).

8 “Art. 22. A alienação fiduciária regulada por esta Lei é o negócio jurídico pelo qual o devedor, ou fiduciante, com o escopo de garantia, contrata a transferência ao credor, ou fiduciário, da propriedade resolúvel de coisa imóvel." (BRASIL, 1997).

9 “Art. 1.238. Aquele que, por quinze anos, sem interrupção, nem oposição, possuir como seu um imóvel, adquire-lhe a propriedade, independentemente de título e boa-fé; podendo requerer ao juiz que assim o declare por sentença, a qual servirá de título para o registro no Cartório de Registro de Imóveis." (BRASIL, 2002).

10 “Art. 167. No Registro de Imóveis, além da matrícula, serão feitos: I - o registro: [...] 42. da conversão da legitimação de posse em propriedade, prevista no art. 60 da Lei no 11.977, de 7 de julho de 2009; [...].” (BRASIL, 1973b). 